Agro-Science Journal of Tropical Agriculture, Food, Environment and Extension Volume 21 Number 1 (January 2022) pp. $22-26$

ISSN 1119-7455

\title{
EFFECTS OF ANIMAL MANURES ON ENZYMES ACTIVITIES AND PHYSICO-CHEMICAL PROPERTIES OF A DEGRADED HUMID ULTISOL
}

\author{
*1 Afangide A.I., ${ }^{1}$ Okoli N.H., ${ }^{1}$ Okon M.A., ${ }^{1}$ Egboka N.T. and ${ }^{2}$ Inyang P. \\ ${ }^{1}$ Department of Soil Science \& Technology, Federal University of Technology, Owerri, Nigeria \\ ${ }^{2}$ Department of Agriculture, Alex Ekwueme Federal University, Ndufu-Alike, Abakaliki, Nigeria \\ *Corresponding author's email: afangideakaninyene2000@gmail.com
}

\begin{abstract}
Application of animal manures for soil amendment plays a major role in the improvement of soil properties and enzymatic activities of a degraded Ultisol. This study assessed the effects of poultry manure (PM) and swine manure (SM) on the activities of catalase and urease enzymes and some soil properties. The PM and SM

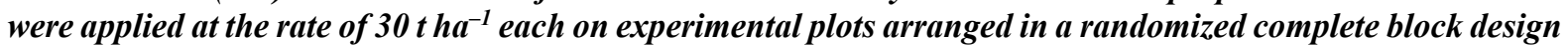
with three replicates. Soil samples were collected at day 0, 14, 28, 42, 56, 70 and 84 from 0-15 and 15-30 cm depths and analyzed for catalase and urease enzymes and some soil properties using standard procedures. The results showed increase in soil pH (in $\mathrm{H}_{2} \mathrm{O}$ ) from 4.0 to 5.4 following manure application. At 0-15 cm soil depth, $P M$ and $S M$ recorded 28.1 and $28.8 \%$ increases in soil $\mathrm{pH}\left(\right.$ in $\mathrm{H}_{2} \mathrm{O}$ ), respectively. Soil organic carbon was highest $\left(2.6 \mathrm{~g} \mathrm{~kg}^{-1}\right)$ at $0-15 \mathrm{~cm}$ depth for soil amended with SM while the lowest value of $1.1 \mathrm{~g} \mathrm{~kg}^{-1}$ was obtained at 15-30 cm depth for soil unamended with SM. In PM-amended soil, catalase activities ranged from 1.32 to $6.77 \mathrm{mg} \mathrm{g}^{-1}$ while its activities in SM-treated soil significantly $(p<0.05)$ varied between 1.55 and $8.11 \mathrm{mg} \mathrm{g}^{-1}$. Urease showed ranges of 0.72-3.90 $\mathrm{mg} \mathrm{g}^{-1}$ and $0.96-4.71 \mathrm{mg} \mathrm{g}^{-1}$ in PM-amended and SM-treated soils, respectively. The results uphold that animal manures improve soil properties and are enzymatically controlled.
\end{abstract}

Key words: catalase, urease, soil amendments, soil properties

\section{INTRODUCTION}

Soil quality is the ability of the soil to perform functions required for the need of the people and the environment. These functions are well-defined by the soil physico-chemical and biological properties of soil. Soil is vital in organic matter decomposition, nutrient cycling and water retention and release. Soil amendments such as animal manures contribute to increases in biological activity as well as to improvements in fertility of the soil. Animal manures play critical role in the soil such as improvement of organic carbon and organic matter (Adebola et al., 2017), amelioration of soil acidity (Nwite et al., 2012; Onunwa et al., 2021), increased release of nutrients (Mohamed et al., 2010; Adubasim et al., 2018), and enhancement of soil microbial and enzyme activities (Afangide et al., 2020; Ogumba et al., 2020). Animal manures serve as substrate for microorganisms which are the main source of soil enzymes that ensure organic matter breakdown (Speir and Ross, 1978; Green et al., 2007). The activities of enzymes are impacted on by environmental factors such as temperature, soil $\mathrm{pH}$ and depth of soil (Peterson and Anderson, 2005). The enzymes involved in decomposition of animal manures are bioindicators and are regarded as a measure of soil quality because of their relation with the cycling of soil minerals and biochemicals in soils (Buturuga et al., 2016).
Catalase $\left(\mathrm{H}_{2} \mathrm{O}_{2}\right.$ oxidoreductase, EC 1.11.1.6) is an enzyme capable of performing critical role in soil fertility. Its activities are connected to the metabolic action of aerobic microorganisms (Shiyin et al., 2004; Trasar-Cepeda et al., 2007). Catalase is an antioxidant enzyme that is capable of breaking down of $\mathrm{H}_{2} \mathrm{O}_{2}$ into water and oxygen without causing free radicals. It is highly stable and demonstrates positive relationship with soil organic carbon; so, it decreases with soil depth (Alef and Nannipieri, 1995). Urease (urease amidohydrolase, EC 3.5.1.5) hydrolyzes urea fertilizers enzymatically into $\mathrm{NH}_{3}$ and $\mathrm{CO}_{2}$ that lead to increases in soil pH (Andrews et al., 1989), causing loss of $\mathrm{N}$ to the atmosphere because of volatilization of urea $\mathrm{N}$ as ammonia (Simpson et al., 1984). However, the activity of urease in soil is of utmost importance due to its ability to regulate the supply of $\mathrm{N}$ to plants after urea application.

Information on catalase and urease activities in humid tropical soils of Uyo amended with animal manures has not been completely elucidated. It is against this backdrop that this study was carried. Therefore, the objectives of this study were to assess the effect of poultry (PM) and swine manures (SW) on catalase and urease activities throughout out the period of decomposition of animal manures and the influence of animal manures on physico-chemical properties of soils of the study area.

Please cite as: Afangide A.I., Okoli N.H., Okon M.A., Egboka N.T. and Inyang P. (2022). Effects of animal manures on enzymes activities and physico-chemical properties of a degraded humid Ultisol. Agro-Science, 21 (1), 22-26. DOI: https://dx.doi.org/10.4314/as.v21i1.4 


\section{MATERIALS AND METHODS \\ Study Area}

The study was carried out in Uyo, southeastern Nigeria. The area lies between latitude $5^{\circ} 01^{\prime} 05^{\prime \prime}$ and $5^{\circ} 01^{\prime} 10^{\prime \prime} \mathrm{N}$ and longitude $7^{\circ} 59^{\prime} 50^{\prime \prime}$ and $7^{\circ} 59^{\prime}$ $55^{\prime \prime}$ E. The area lies within the humid tropics characterized by high temperature with annual range of 26 to $31^{\circ} \mathrm{C}$, while rainfall is averaging between 2000 to $2500 \mathrm{~mm}$. Relative humidity is about $75 \%$. The rainfall pattern is bimodal with peak in July and a short period of dry spell in August known as August break. Degraded Ultisol having no apparent spatial differences in soil properties and has been under cultivation for more than 20 years was used for the study. The soil Typic paleudults derived from coastal plain sand (Orajiaka, 1975).

\section{Field Study}

The experimental field selected for the study was cleared, ploughed, harrowed and mapped out into experimental plots. Each plot size was $3 \times 3 \mathrm{~m}$ separated by $1 \mathrm{~m}$ path arranged in a randomized complete block design with three replicates. The treatments were cured poultry manure (PM) from deep litter broiler pen and swine manure (SM) obtained from the University of Uyo Teaching and Research Farm, Nigeria. The treatments application rate was $30 \mathrm{t} \mathrm{ha}^{-1}$ and the treatments were allowed to decompose for a period of ninety days. Using soil auger and sterilized polyethene bag, soil samples were collected from depths $0-15 \mathrm{~cm}$ and $15-30 \mathrm{~cm}$ during the decomposition time at day $0,14,28,42$, 56,70 and 84 . A total of 12 samples were obtained in every week, summing to a total of 84 samples for enzymatic analyses. Soil samples were also obtained for physico-chemical analyses before treatments were applied on the soil and after 90 days of decomposition of the treatments.

\section{Laboratory Analyses}

The soil samples were air-dried, sieved through a 2$\mathrm{mm}$ sieve and sent to laboratory for analyses. The analyses carried out were particle size distribution as described by Gee and Or (2002); soil pH, measured using glass electrode (Thomas, 1996); organic carbon determined using modified Walkley-Black procedure (Nelson and Sommers, 1996); total nitrogen determined by Macro-Kjedahl method (Bremner, 1996); available phosphorus determined using calorimetric method (Olson and Sommers, 1982); and effective cation exchange capacity and exchangeable acidity, following the procedures described by Thomas (1996). The manures were air-dried and hammermilled to obtain particle less than $1.5 \mathrm{~mm}$ in size. Manures were characterized by the method proposed by Kaira and Maynard (1991).

\section{Determination of Urease Activity}

A $5 \mathrm{~g}$ moist soil sample mixed with $1 \mathrm{ml}$ of toluene in a $50 \mathrm{ml}$ Erlenmeyer flask was allowed to remain for $15 \mathrm{~min}$. (Gu et al., 2009). Then $10 \mathrm{ml}$ of $1 \%$ urea solution and $20 \mathrm{ml}$ citrate buffer $(\mathrm{pH}$ 6.7) were added, thoroughly mixed, and kept in an incubator for at $37^{\circ} \mathrm{C}$ for $24 \mathrm{~h}$. The soil was filtered through Whatman 42 filter paper after it was incubated. The $50 \mathrm{ml}$ test tubes used were filled with $3 \mathrm{ml}$ aliquot and $4 \mathrm{ml}$ sodium phenol and $3 \mathrm{ml}$ sodium hypochlorite were added. After $20 \mathrm{~min}$., the final volume was made to $50 \mathrm{ml}$ using distilled water, the absorbance of the release urease was measured when the colour was developed at room temperature at $578 \mathrm{~nm}$ and the result expressed as $\mathrm{mg} \mathrm{NH}_{4}-\mathrm{N}$ in $\mathrm{Mg} \mathrm{g}^{-1}$ soil.

\section{Determination of Catalase Activity}

A 3-g moist soil sample was measured and added to a $50 \mathrm{ml}$ Erlenmeyer flask, $40 \mathrm{ml}$ of distilled water, 5 $\mathrm{ml}$ of $3 \%$ hydrogen peroxide $\left(\mathrm{H}_{2} \mathrm{O}_{2}\right)$ and $5 \mathrm{ml}$ of $\mathrm{KMnO}_{4}$ were added. Thereafter, $10 \mathrm{ml}$ phosphate buffer ( $\mathrm{pH}$ 6.5) were added and shaken for $20 \mathrm{~min}$. with the help of an end-to-end shaker as described by Cohen et al. (1970). The reaction was terminated by an addition of $10 \mathrm{ml}$ of $3 \mathrm{NH}_{2} \mathrm{SO}_{4}$ after it was shaken. Catalase was measured calorimetrically at $480 \mathrm{~nm}$ and the result recorded as $\mathrm{mg} \mathrm{H}_{2} \mathrm{O}_{2} \mathrm{~g}^{-1}$ of soil.

\section{Statistical Analysis}

Data on urease, catalase and soil physicochemical properties were subjected to analysis of variance using the software package (SAS, 1999). Treatment means that differed significantly at $p \leq 0.05$ were separated using the Duncan's new multiple range test.

\section{RESULTS AND DISCUSSION \\ Manure Characterization}

Table 1 shows chemical characteristics of poultry and swine manures. Poultry manure was higher in $\mathrm{pH}$, organic matter and available phosphorus. Higher level of chemical properties of poultry manure such as $\mathrm{pH}$, available phosphorus, and organic matter may be due to variations in feed given to poultry, mineral supplements and bedding materials. It has been observed that fluctuation in animal diet, age, type, environment and productivity may cause differences in chemical properties of poultry manures (Afangide et al., 2020). Swine manure recorded higher amount of total nitrogen, organic carbon and $\mathrm{CN}$ ratio. By this higher $\mathrm{CN}$ ratio, the rate of mineralization is expected to be lower in the soil amended with swine manure relative to the soil amended with poultry manure (Azam, 2002; Uzoh et al., 2015). The soil physicochemical properties of the control site and manure amended soil are shown in Tables 2 and 3.

Table 1: Some chemical characteristics of the animal manures used for the study

\begin{tabular}{lcc}
\hline Properties & $\begin{array}{c}\text { Poultry } \\
\text { manure }\end{array}$ & $\begin{array}{c}\text { Swine } \\
\text { manure }\end{array}$ \\
\hline Total nitrogen $\left(\mathrm{g} \mathrm{kg}^{-1}\right)$ & 44.2 & 52.4 \\
Organic matter $\left(\mathrm{g} \mathrm{kg}^{-1}\right)$ & 724.3 & 648 \\
Organic carbon $\left(\mathrm{g} \mathrm{kg}^{-1}\right)$ & 290 & 373 \\
Available phosphorus $\left(\mathrm{mg} \mathrm{kg}^{-1}\right)$ & 19.2 & 15.0 \\
$\mathrm{C} / \mathrm{N}$ & 5.3 & 7.8 \\
$\mathrm{pH}-\mathrm{H}_{2} \mathrm{O}$ & 7.58 & 6.62 \\
\hline
\end{tabular}


Table 2: Physico-chemical properties of the soils of the study area before application of animal manure

\begin{tabular}{lllll}
\hline & $0-15 \mathrm{~cm} \mathrm{P}$ & $15-30 \mathrm{~cm} \mathrm{P}$ & $0-15 \mathrm{~cm} \mathrm{~S}_{1}$ & $15-30 \mathrm{~cm} \mathrm{~S}_{1}$ \\
\hline Sand $\left(\mathrm{g} \mathrm{kg}^{-1}\right)$ & $862 \mathrm{~b}$ & $877 \mathrm{a}$ & $855 \mathrm{~b}$ & $852 \mathrm{a}$ \\
$\mathrm{Silt}\left(\mathrm{g} \mathrm{kg}^{-1}\right)$ & $52.3 \mathrm{acd}$ & $36.0 \mathrm{abc}$ & $62.0 \mathrm{ab}$ & $49.0 \mathrm{abc}$ \\
$\mathrm{Clay}\left(\mathrm{g} \mathrm{kg}^{-1}\right)$ & $85.7 \mathrm{c}$ & $87.3 \mathrm{bc}$ & $83.0 \mathrm{c}$ & $99.0 \mathrm{a}$ \\
$\mathrm{pH} \mathrm{in} \mathrm{H}_{2} \mathrm{O}$ & $4.2 \mathrm{c}$ & $4.1 \mathrm{~d}$ & $4.1 \mathrm{c}$ & $4.0 \mathrm{c}$ \\
Soil organic carbon, SOC $\left(\mathrm{g} \mathrm{kg}^{-1}\right)$ & $1.4 \mathrm{~b}$ & $1.1 \mathrm{~b}$ & $1.3 \mathrm{ab}$ & $1.1 \mathrm{~b}$ \\
Total Nitrogen, $\mathrm{N}\left(\mathrm{g} \mathrm{kg}^{-1}\right)$ & $0.1 \mathrm{bc}$ & $0.1 \mathrm{~cd}$ & $0.1 \mathrm{a}$ & $0.0 \mathrm{~cd}$ \\
Available phosphorus, $\mathrm{P}\left(\mathrm{mg} \mathrm{kg}^{-1}\right)$ & $43.3 \mathrm{bcd}$ & $34.7 \mathrm{~d}$ & $42.0 \mathrm{bc}$ & $35.0 \mathrm{ac}$ \\
Effective cation exchange capacity, ECEC $\left(\mathrm{cmol} \mathrm{kg}^{-1}\right)$ & $10.4 \mathrm{c}$ & $10.2 \mathrm{c}$ & $10.3 \mathrm{c}$ & $9.8 \mathrm{~b}$ \\
\hline
\end{tabular}

Mean values with the same letter (s) within the rows are not significantly different from one another at $p<0.05$.

$P_{l}$ and $S_{l}$ represent control soil (untreated) with poultry and swine manures, respectively.

Table 3: Physico-chemical properties of the soils of the study area 90 days after application of animal manures

\begin{tabular}{lllll}
\hline & $0-15 \mathrm{~cm} \mathrm{P}_{2}$ & $15-30 \mathrm{~cm} \mathrm{P}_{2}$ & $0-15 \mathrm{~cm} \mathrm{~S}_{2}$ & $15-30 \mathrm{~cm} \mathrm{~S}_{2}$ \\
\hline Sand $\left(\mathrm{g} \mathrm{kg}^{-1}\right)$ & $846 \mathrm{a}$ & $862 \mathrm{a}$ & $840 \mathrm{~b}$ & $842 \mathrm{~b}$ \\
$\mathrm{Silt}\left(\mathrm{g} \mathrm{kg}^{-1}\right)$ & $48.0 \mathrm{~d}$ & $22.0 \mathrm{~cd}$ & $42.0 \mathrm{acd}$ & $38.0 \mathrm{~d}$ \\
$\mathrm{Clay}\left(\mathrm{g} \mathrm{kg}^{-1}\right)$ & $106 \mathrm{ab}$ & $116 \mathrm{abc}$ & $118 \mathrm{~cd}$ & $120 \mathrm{ab}$ \\
$\mathrm{pH} \mathrm{in} \mathrm{H}_{2} \mathrm{O}$ & $5.4 \mathrm{a}$ & $4.8 \mathrm{a}$ & $5.2 \mathrm{a}$ & $4.7 \mathrm{ab}$ \\
Soil organic carbon, SOC $\left(\mathrm{g} \mathrm{kg}^{-1}\right)$ & $2.3 \mathrm{a}$ & $2.0 \mathrm{a}$ & $2.6 \mathrm{a}$ & $2.0 \mathrm{a}$ \\
Total nitrogen, $\mathrm{N}\left(\mathrm{g} \mathrm{kg}^{-1}\right)$ & $0.1 \mathrm{a}$ & $0.1 \mathrm{~b}$ & $0.1 \mathrm{a}$ & $0.1 \mathrm{bc}$ \\
Available phosphorus, $\mathrm{P}\left(\mathrm{mg} \mathrm{kg}^{-1}\right)$ & $72.0 \mathrm{~b}$ & $65.0 \mathrm{ab}$ & $68.0 \mathrm{ab}$ & $62.0 \mathrm{~b}$ \\
Effective cation exchange capacity, ECEC $\left(\mathrm{cmol} \mathrm{kg}^{-1}\right)$ & $18.3 \mathrm{a}$ & $13.9 \mathrm{~b}$ & $16.8 \mathrm{a}$ & $13.4 \mathrm{~b}$ \\
\hline
\end{tabular}

Mean values with the same letter (s) within the rows are not significantly different from one another at $p<0.05$.

$P_{l}$ and $S_{l}$ represent control soil (untreated) with poultry and swine manures, respectively.

Sand, silt and clay contents showed values in the ranges of 840-877, 22.0-62.0 and 83.0-120.0 $\mathrm{g} \mathrm{kg}^{-1}$, respectively. The dominance of sand-sized particle may be due to abundance of rainfall in the area which promotes erosion menace (Abraham, 2010). Consequently, the increase in clay fractions with soil depth could be attributed to illuviation of clay and its translocation, which is accelerated by increase in runoff impact due to high rainfall (Obi et al., 2009). Soil $\mathrm{pH}$ in $\mathrm{H}_{2} \mathrm{O}$ was generally acidic 4.0-5.4. This can be attributed to acidic nature of the parent material (Ndukwu et al., 2012). Poultry manure treated soil recorded $28.1 \%$ increase of soil $\mathrm{pH}$ at the 0-15 cm soil depth while swine manure treated soil increased by $28.8 \%$ also at $0-15 \mathrm{~cm}$ soil depth. Similarly, soil $\mathrm{pH}$ of poultry manure amended plots increased by $18.1 \%$ at $15-30 \mathrm{~cm}$ soil depth while swine manure amended soil recorded $17.9 \%$ increase at $15-30 \mathrm{~cm}$ soil depth following manure application. Low values of soil $\mathrm{pH}$ less than 5.5 may be due to high amount of rainfall in the region which promotes leaching of basic cations from the soil (Uzoho et al., 2007). Some chemical properties of the soil including soil organic carbon, total $\mathrm{N}$, available $\mathrm{P}$ and effective cation exchange capacity were low and decreased significantly $(p<0.05)$ with increased soil depth. Total $\mathrm{N}$ recorded highest value at the $0-15 \mathrm{~cm}$ soil depth treated with swine manure. Also, soil organic carbon was highest at the $0-15 \mathrm{~cm}$ soil depth amended with swine manure. These may be ascribable to higher level of animal manures on the surface layer soil (Zhijin et al., 2013).
Table 4 shows dynamics of catalase and urease enzymes and their variations across animal manures. Dynamics of catalase activities ranged from 1.32 to $6.77 \mathrm{mg} \mathrm{g}^{-1}$ in amended soil with poultry manure while its activities in swine manure treated soil varied between $1.558 .11 \mathrm{mg} \mathrm{g}^{-1}$. Catalase was highest in the soil at $0-15 \mathrm{~cm}$ soil depth at week 2 of decomposition. This may be attributable to higher microbial abundance in the surface layer of the soil since the deepest layers usually have reduced number of microbial cell and subsequently, enzyme level showed decreasing trend. But due to humid rainfall characteristic of the area which promotes high leaching and mineralization of the animal manures, $15-30 \mathrm{~cm}$ soil depth recorded a significant increase in enzymes production. Similar observations were made by Chang et al. (2007) who reported that catalase production is a function of organic matter level of the soil. Catalase activities were higher in poultry manure treated soil than swine manure treated soil. The increase of catalase may be associated with a decrease in the nitrogen level of poultry manure when compared to swine manure during characterization (Table 1). This in is line with Xia et al. (2017) who reported that, increase in nitrogen level of animal manures will lead to a decrease and a negative relationship with catalase activity. Urease ranged from 0.72 to $3.90 \mathrm{mg} \mathrm{g}^{-1}$ in amended soil with poultry manure whereas in soil amended with swine manure, urease varied between 0.96 and $4.71 \mathrm{mg} \mathrm{g}^{-1}$. The amount of urease was higher in swine manure amended soil when related to 
Table 4: Changes in catalase and urease activity in topsoil and subsoil treated with poultry and swine manures

\begin{tabular}{lllll}
\hline Duration & \multicolumn{2}{c}{ Catalase $\left(\mathrm{mg} \mathrm{g}^{-1}\right)$} & \multicolumn{2}{c}{ Urease $\left(\mathrm{mg} \mathrm{g}^{-1}\right)$} \\
\cline { 2 - 3 } & $0-15 \mathrm{~cm}$ & $15-30 \mathrm{~cm}$ & $0-15 \mathrm{~cm}$ & $15-30 \mathrm{~cm}$ \\
\hline Week 0 & $1.48 \mathrm{a}$ & $1.32 \mathrm{a}$ & $1.08 \mathrm{~b}$ & $0.72 \mathrm{~b}$ \\
Week 2 & $4.42 \mathrm{a}$ & $1.95 \mathrm{~b}$ & $2.50 \mathrm{a}$ & $2.24 \mathrm{a}$ \\
Week 4 & $3.38 \mathrm{~b}$ & $5.96 \mathrm{ab}$ & $2.15 \mathrm{a}$ & $2.52 \mathrm{ab}$ \\
Week 6 & $2.90 \mathrm{a}$ & $6.77 \mathrm{ab}$ & $2.14 \mathrm{a}$ & $3.90 \mathrm{~b}$ \\
Week 8 & $2.43 \mathrm{~b}$ & $3.92 \mathrm{ab}$ & $2.04 \mathrm{a}$ & $2.51 \mathrm{a}$ \\
Week 10 & $2.33 \mathrm{ab}$ & $2.89 \mathrm{a}$ & $1.76 \mathrm{~b}$ & $1.97 \mathrm{~b}$ \\
Week 12 & $1.88 \mathrm{~b}$ & $2.50 \mathrm{ab}$ & $1.29 \mathrm{a}$ & $1.21 \mathrm{a}$ \\
& & Swine manure treated soil & \\
Week 0 & $1.72 \mathrm{~b}$ & $1.55 \mathrm{~b}$ & $1.08 \mathrm{a}$ & $0.96 \mathrm{~b}$ \\
Week 2 & $5.25 \mathrm{a}$ & $2.10 \mathrm{~b}$ & $4.05 \mathrm{a}$ & $1.89 \mathrm{~b}$ \\
Week 4 & $4.26 \mathrm{~b}$ & $7.14 \mathrm{ab}$ & $3.07 \mathrm{a}$ & $4.08 \mathrm{a}$ \\
Week 6 & $4.04 \mathrm{a}$ & $8.11 \mathrm{ab}$ & $2.65 \mathrm{~b}$ & $4.71 \mathrm{a}$ \\
Week 8 & $2.61 \mathrm{~b}$ & $5.28 \mathrm{ab}$ & $1.53 \mathrm{a}$ & $2.02 \mathrm{a}$ \\
Week 10 & $1.82 \mathrm{~b}$ & $2.65 \mathrm{~b}$ & $1.34 \mathrm{a}$ & $2.14 \mathrm{~b}$ \\
Week 12 & $1.79 \mathrm{~b}$ & $3.00 \mathrm{ab}$ & $1.16 \mathrm{a}$ & $1.69 \mathrm{a}$ \\
\hline
\end{tabular}

Mean values with the same letter (s) within the rows are not significantly different from one another at 5\% probability level

poultry manure amended soil. The observed increase may be largely due to high amount of $\mathrm{N}$ in pig manure than poultry manure (see Table 1), since increase in $\mathrm{N}$ often leads to increase in urease activity (Kilzilkaya and Elberli, 2008).

\section{CONCLUSION}

This research showed that animal manures improved some chemical properties of the soil such as $\mathrm{pH}$, organic carbon and total nitrogen were improved after manure application. There was elevated amount of catalase and urease activities at the second week of manure decomposition (14 days after application) of poultry and swine manures while sub-surface layer of the soil produced the highest amount of catalase and urease at the sixth week of decomposition (42 days after application) of the manures. Urease activity was highest in swine manure amended soil whereas catalase activity was highest in poultry manure amended soil. Based on this finding it is better to allow animal manures to decompose at least two weeks prior to planting of crops.

\section{REFERENCES}

Abraham C.M. (2010). Implications of Gully Development on Agricultural Production in Akwa Ibom State. A PhD Thesis, Department of Geography and Regional Planning, University of Uyo, Akwa Ibom State, Nigeria

Adebola A.E., Ewulo B.S. and Arije D.N. (2017). Effects of different animal manures on soil physical and microbial properties. Appl. Trop. Agric., 22 (1), 128-133

Adubasim C.V., Igwenagu C.M., Josiah G.O., et al. (2018). Substitution of manure source and aerator in nursery media on sandy-loam topsoil and their fertility indices 4 months after formulation. Int. J. Recycl. Org. Waste Agric., 7(4), 305-312. DOI: 10.1007/s40093-018-0216-8

Afangide A.I., Ekpe I.I., Okoli N.H. and Egboka N.T. (2020). Dynamics of phosphatase enzymes and microbial properties in a degraded ultisol amended with animal manures. J. Clean WAS, 4 (1), 21-27
Alef K. and Nannipieri P. (1995). Catalase activity. In: Methods in Applied Soil Microbiology and Biochemistry (pp. 362-363). Academic Press, London

Andrews R.K., Blakeley R.L. and Zerner B. (1989). Urease: A. Nickel (II) metalloenzyme. In: Lancaster J.R. (ed.), The Bioinorganic Chemistry of Nickel (pp. 141-166). VCH, New York, USA

Azam F. (2002). Added nitrogen interaction in the soilplant system: A review. Pak. J. Agric., 1, 54-59

Bremner J.M. (1996). Total nitrogen. In: Sparks D.L. (ed.), Methods of Soil Analysis Part 3: Chemical Methods (pp. 1085-1122). Soil Science Society of America Book Series, Soil Science Society of America \& American Society of Agronomy, Madison, WI

Buturuga M.D., Stefanic G., Sandoiu D.I. and Badulescu L. (2016). Ecological methods of pedo-enzymatical analysis for soil fertility control. Rom. Biotechnol., 21 (3), 11471

Chang E.H., Chung R.S. and Tsai Y.H. (2007). Effect of different application rates of organic fertilizer on soil enzyme activity and microbial population. J. Soil Sci. Plant Nutr., 53, 132-140

Cohen D., Dembiec D. and Marcus J. (1970). Measurement of catalase activity in tissue extract. $J$. Anim. Biochem., 34, 30-38

Gee G.W. and Or D. (2002). Particle size distribution. In: Dane, J.H. and Topp G.C. (eds.), Methods of Soil Analysis Part 4: Physical and Mineralogical Methods (pp. 255-293). Soil Science Society of America Book Series No. 5, American Society of Agronomy and Soil Science Society of America, Madison, WI

Green V.S., Stott J.C., Cruz D.E. and Curi N. (2007). Tillage impacts on soil biological activities and aggregation in a Brazilian cerrado oxisol. Soil Till. Res., 92, 114-121

Gu Y., Wang P. and Kong C.H. (2009). Urease, invertase, dehydrogenase and polyphenoloxidase activities in paddy soil influenced by aleopathic rice variety. Europ. J. Soil Biol., 30, 1-6

Kaira Y.P. and Maynard D.G. (1991). Methods Manual for Information and Plant Analysis. Information Report NOR-X-319E, Northwest Region, Northern Forestry Centre, Edmonta, Alberta. 116 pp. 
Kilzilkaya R. and Elberli I. (2008). Determination of the effect of hazelnut husk and tea waste treatments of urease activity and the kinetics in soil. Turk. J. Agric. Forestry, 32, 299-310

Mohamed A.M., Sekar S. and Muthkrishnan P. (2010). Prospects and potential of poultry manure. Asian $J$. Plant Sci., 9, 172-182

Ndukwu B.N., Chukwuma M.C., Idigbo C.M. and Obasi S.N. (2012). Forms and distribution of potassium in soils underlain by three lithologies in Southeastern Nigeria. Int. J. Agric. Rural Dev., 15 (2), 1104-1108

Nelson D.W. and Sommers L.E. (1996). Total carbon, organic carbon and organic matter. In: Sparks D.L. (ed.), Methods of Soil Analysis, Part3: Chemical Methods (pp. 96-101). Soil Science Society of America Book Series, Soil Science Society of America and American Society of Agronomy, Madison, WI

Nwite J.C., Essien B.A., Anaele M.U., Obalum S.E., Keke C.I. and Igwe C.A. (2012). Supplementary use of poultry droppings and rice-husk waste as organic amendments in southeastern Nigeria. 1. soil chemical properties and maize yield. Libyan Agric. Res. Centre J. Int., 3 (2), 90-97

Obi J.C., Akinbola G.E. and Anazie H.I. (2009). Distribution of dithionite and oxalate extractable iron oxides of a catena in the basement complex of Southwest Nigeria. Nig. J. Soil Sci., 19, 100-119

Olson S.R. and Sommers L.E. (1982). Phosphorus. In: Page A.L., (ed.), Method of Soil Analysis, Part 2, $2^{\text {nd }}$ ed., (pp. 403-430). American Society of Agronomy and Soil Science Society of America, Madison, WI

Ogumba P.O., Obalum S.E. and Uzoh I.M. (2020). Soil biochemical and microbial properties of sandy loam Ultisols as affected by some tillage and nutrient management practices. Int. J. Agric. Rural Dev., 23 (2), 5184-5195

Onunwa A.O., Nwaiwu C.J., Nwankwor J.E., Emeh C.E., Madueke C.O. and Igwe C.A. (2021). Effects of four organic amendments on soil physicochemical properties and yield of maize (Zea mays) and cowpea (Vigna unguiculata) intercrop in Awka, Southeastern Nigeria. Agro-Science, 20 (2), 49-56

Orajiaka S.O. (1975). Nigeria in Maps: Eastern States (pp. 5-7). In: Ofomata G.E.K. (eds). Benin City: Ethiope Publishing House
Peterson C.E. and Anderson B.J. (2005). Investigation in the Biological 1151 Laboratory. Stipes LLC Print., Champaign, IL

SAS (1999). The SAS System for Windows. Release 8.0. SAS Institute, Cary, NC

Shiyin L., Lixiao O., Panying P., Cheng S. and Liansheng W. (2004). Effect of pesticides and their hydrololysates on catalase activity in soil. Bull. Environ. Contam. Toxicol., 72, 600-606

Simpson J.R., Freney R.R., Wetselaar R., Muirhead W.A., Leuning R. and Denmead O.T. (1984). Transformations and losses of urea nitrogen after application to flooded rice. Aust. J. Agric., 35, 189-200

Speir T.W. and Ross D.T. (1978). Soil phosphatase and sulphatase. In: Burns R.G. (ed.), Soil Enzymes (p. 380). Academic Press, New York

Thomas G.W. (1996). Soil pH and soil acidity. In: Sparks D.L., Page A.L., Helmke P.A. et al. (eds.), Methods of Soil Analysis Part 3: Chemical Methods (pp. 475-490). Soil Science Society of America and American Society of Agronomy, Madison, WI

Trasar-Cepeda C., Gil-Sotres F. and Leiros M.C. (2007). Thermodynamics parameters of enzymes in grassland soils from Galicia, NW Spain. Soil Biol. Biochem., 39, 311-319

Uzoh I.M., Obalum S.E. and Ene J. (2015). Mineralization rate constants, half-lives and effects of two organic amendments on maize yield and carbon-nitrogen status of loamy Ultisol in southeastern Nigeria. Agro-Science, 14 (3), 35-40. http://dx.doi.org/10.4314/as.v14i3.7

Uzoho B.U., Oti N.N. and Ngwuta A. (2007). Fertility status under land use types on soils of the similar lithology. J. Am. Sci., 3 (4), 20-29

Xia L., Lam S.K., Yan X. and Chen D. (2017). How does recycling of livestock manure in agroecosystems affect crop productivity, reactive nitrogen losses and soil carbon balance? Environ. Sci. Technol., 51, 7450

Zhijin X., Cheng M. and An S. (2013). Soil nitrogen distributions of different land uses and landscape positions in a small watershed on Loess plateau, China. J. Ecol. Eng., 60, 204-213 